\title{
Cloning and expression of an active aspartic proteinase from Mucor circinelloides in Pichia pastoris
}

\author{
Jose Antonio Gama Salgado ${ }^{\dagger}$, Martin Kangwa ${ }^{\dagger}$ and Marcelo Fernandez-Lahore ${ }^{*+}$
}

\begin{abstract}
Background: Extracellular aspartic proteinase (MCAP) produced by Mucor circinelloides in solid state fermentations has been shown to possess milk clotting activity and represents a potential replacement for bovine chymosin in cheese manufacturing. Despite its prospects in the dairy industry, the molecular characteristics of this enzyme remain unknown. This work focuses on MCAP cloning and optimization of heterologous expression in Pichia pastoris, and characterization of the enzyme.
\end{abstract}

Results: The cloning of CDNA sequence encoding MCAP from M. circinelloides was performed using a fragment of approximately $1 \mathrm{kbp}$ as a probe. The fragment was amplified using non-specific primers designed from the NDIEYYG and KNNYWFN consensus motifs from aspartic proteinases of different fungi. Gene specific primers were designed to amplify a full-length CDNA using SMARTTM RACE PCR. MCAP was expressed in P. pastoris under the control of the constitutive GAP promoter. It was shown that $P$. pastoris secreted non-glycosylated and glycosylated MCAPs with molecular weights of 33 and $37 \mathrm{kDa}$, respectively.

Conclusion: A novel MCAP was expressed in P. pastoris and efficiently secreted into the culture medium. The expression of the heterologous proteins was significantly increased due to advantages in codon usage as compared to other expression systems. The results suggest that $P$. pastoris could be exploited as a safe production platform for the milk clotting enzyme.

Keywords: Aspartic proteinase, Mucor circinelloides, Pichia pastoris, SMART'M RACE PCR (Rapid Amplification of cDNA Ends), Alpha factor secretion signal, Milk clotting units (MCU)

\section{Background}

Rennet, a milk coagulant from the abomasum of milkfed calves and lambs, is the industrial gold standard in cheese manufacturing [1]. Chymosin is the major milkclotting component of natural rennet preparations obtained from young animals as its activity amounts to $90 \%$ of the total observed potency [2]. However, due to increased demand in cheese products, animal-derived milk coagulants are not sufficient to cover the production. Therefore, the demand has prompted increased research efforts in the manufacture of recombinant and microbial rennin [3]. Nevertheless, the rennin of microbial origin might be contaminated by other enzymes

\footnotetext{
* Correspondence: m.fernandez-lahore@jacobs-university.de

${ }^{\dagger}$ Equal contributors

School of Engineering and Science, Jacobs University Bremen, Campus Ring 1, Bremen 28759, Germany
}

which might affect cheese ripening by causing bitterness during storage [4].

Until now, several aspartic proteinases (APs) such as pepsin, rennin, renin, and cathepsin D have been extensively studied. Microbial APs such as rhizopuspepsin and penicillopepsin have been reported to be either intracellular or extracellular enzymes with most of them having been cloned and purified. For example, acid proteinase from Metschnikowia reukaufii [5] has been cloned and expressed in Escherichia coli while three clt genes encoding milk-clotting proteinases from Myxococcus xanthus have been cloned and expressed in E. coli, Saccharomyces cerevisiae and P. pastoris [3].

It is also known that fungal extracellular thermophilic proteinases from $R$. miehei and $R$. pusillus are still used as substitutes for calf chymosin in cheese manufacturing [6]. However, the enzymes are extensively proteolytic 
which may result in impaired cheese organoleptic characteristics. Moreover, the proteinases are resistant to heat treatment compared to bovine chymosin and thus can remain active in the curd for longer periods of time [7]. Additionally, proteinases with low heat stability have been observed in M. varians [8] and M. circinelloides [9]. Although studies on the characterization of an acid proteinase from $M$. circinelloides were performed, the molecular characteristics of the enzyme remain unknown. The mentioned thermo-labile proteinases may provide technological advantages for industrial utilization. In this work, the cloning and expression of the aspartic proteinase from M. circinelloides was performed.

\section{Methods}

\section{Fungal strain, bacterial strains and plasmids}

The microorganism used as the source of the gene encoding MCAP was M. circinelloides strain DSM 2183 (Deutsche Sammlung von Mikroorganismen und Zellkulturen $\mathrm{GmbH}$, Braunschweig, Germany). E. coli strain TOP10 [10] was used to amplify the plasmids carrying the cloned gene. E. coli strains were grown overnight in Luria-Bertani medium $\left(10 \mathrm{~g} \mathrm{~L}^{-1}\right.$, tryptone, $5 \mathrm{~g} \mathrm{~L}^{-1}$ yeast extract, $\left.5 \mathrm{~g} \mathrm{~L}^{-1} \mathrm{NaCl}\right)$ at $37^{\circ} \mathrm{C}, 220 \mathrm{rpm}$. P. pastoris was grown in YPD medium $\left(10 \mathrm{~g} \mathrm{~L}^{-1}\right.$ yeast extract, $20 \mathrm{~g} \mathrm{~L}^{-1}$ peptone, $20 \mathrm{~g} \mathrm{~L}^{-1}$ glucose) at $30^{\circ} \mathrm{C}$ for 3 days with shaking at $250 \mathrm{rpm}$. When required, the final antibiotics concentration for ampicillin was $100 \mu \mathrm{g} \mathrm{mL} \mathrm{m}^{-1}$ while for zeocin it was either 30,50 or $100 \mu \mathrm{g} \mathrm{mL} \mathrm{m}^{-1}$. Plasmid pGAPZ $\alpha$-A (Invitrogen, Darmstadt, Germany) was used as the cloning and expression vector. Table 1 shows the plasmids and strains used in this study.

\section{Genomic DNA extraction}

For genomic DNA extraction, M. circinelloides DSM 2183 spores $\left(1 \times 10^{5}\right.$ spores $)$ were inoculated into potato dextrose agar plates (PDA) which were incubated at $24^{\circ} \mathrm{C}$ for 3 days. The PDA medium was prepared according to the supplier's protocol (Difco, Detroit, MI, USA). About $250 \mathrm{mg}$ of fresh mycelium were collected with tweezers in a $1.5 \mathrm{~mL}$ vial. The mycelium were washed with sterile water and centrifuged at $5000 \mathrm{~g}$ for $2 \mathrm{~min}$. The spores were lysed in $466 \mu \mathrm{L}$ TE buffer $(10 \mathrm{mM}$ Tris-Cl, $\mathrm{pH}$ 8.0, $1 \mathrm{mM}$ EDTA) with $3 \mu \mathrm{L}$ Proteinase $\mathrm{K}\left(20 \mathrm{mg} \mathrm{mL}^{-1}\right), 1 \mu \mathrm{L}$ RNAse $\left(10 \mathrm{mg} \mathrm{mL}^{-1}\right)$ and $30 \mu \mathrm{L}$ SDS $\left(100 \mathrm{mg} \mathrm{mL}^{-1}\right)$. The suspension was mixed gently to avoid shearing the chromosomal DNA, followed by incubation at $37^{\circ} \mathrm{C}$ for $1 \mathrm{~h}$. The precipitated DNA was collected by centrifugation

Table 1 List of microorganisms and plasmids used in this study

\begin{tabular}{|c|c|c|}
\hline Strain or plasmid & Genotype & Reference \\
\hline \multicolumn{3}{|l|}{ Strains } \\
\hline \multicolumn{3}{|l|}{ Escherichia coli } \\
\hline TOP10 & $\begin{array}{l}\text { F- mcrA } \Delta \text { (mrr-hsdRMS-mcrBC) } \varphi 80 \text { lacZ } \Delta \text { M15 } \Delta \text { lacX74 recA1 araD139 } \Delta \text { (ara-leu) } \\
7697 \text { galU galK rpsL (StrR) endA1 nupG }\end{array}$ & 10 \\
\hline \multicolumn{3}{|l|}{ Pichia pastoris } \\
\hline$x-33$ & Wild type & Invitrogen \\
\hline \multicolumn{3}{|l|}{ Mucor circinelloides } \\
\hline DSM 2183 & Wild type & $\begin{array}{l}\text { German resource centre for } \\
\text { biological material }\end{array}$ \\
\hline \multicolumn{3}{|l|}{ Plasmids } \\
\hline pGAPZa-A & $\begin{array}{l}\text { The pGAPZa-A vector use the GAP promoter to constitutively express recombinant } \\
\text { proteins in Pichia pastoris. Contains the zeocin resistance gene (Sh ble). }\end{array}$ & Invitrogen \\
\hline pGAPZa+MCAP & pGAPZa-A derivative carrying the whole MCAP gene ${ }^{1}$. & This work \\
\hline pGAPZa+MCAP-2 & pGAPZa-A derivative carrying the MCAP gene without an intron'. & This work \\
\hline pGAPZa+MCAP-3 & pGAPZa-A derivative carrying the MCAP gene without an intron ${ }^{2}$. & This work \\
\hline pGAPZa+MCAP-5 & $\begin{array}{l}\text { pGAPZa-A derivative carrying the MCAP gene without a signal sequence and } \\
\text { without an intron }{ }^{2} \text {. }\end{array}$ & This work \\
\hline pGAPZa+MCAP SP-1 & $\begin{array}{l}\text { pGAPZa-A derivative carrying from the amino acid sequence number } 67 \text { to } 394 \\
\text { of the MCAP gene without an intron?. }\end{array}$ & This work \\
\hline pGAPZa+SyMCAP-6 & $\begin{array}{l}\text { pGAPZa-A derivative carrying the MCAP gene without signal sequence and without intron. } \\
\text { The original MCAP gene was adapted to the optimal codon usage of P. pastoris. The insert } \\
\text { was cloned flush with the Kex } 2 \text { cleavage site and in frame of the a- factor signal sequence and in } \\
\text { frame with the C-terminal polyhistidine tag into the Xhol and Notl site of the pGAPZa-A. }\end{array}$ & This work \\
\hline
\end{tabular}

${ }^{1}$ The insert was cloned in frame with the a-factor signal sequence and in frame with the C-terminal polyhistidine tag into the EcoRI and Notl sites of the pGAPZa-A. ${ }^{2}$ The insert was cloned flush with the Kex2 cleavage site and in a frame of the a-factor signal sequence and in a frame with the C-terminal polyhistidine tag into the Xhol and Notl site of the pGAPZa-A. 
$\left(15000 \mathrm{~g}, 10 \mathrm{~min}\right.$ at $\left.4^{\circ} \mathrm{C}\right)$, followed by phenol-chloroform extraction and ethanol precipitation as described [11].

\section{DNA manipulation}

Restriction enzymes (EcoRI, XhoI, NotI and AvrII), T4 DNA ligase and Taq DNA polymerase were purchased from New England Biolabs (Frankfurt, Germany). All enzymes were used under the conditions specified by the manufacturer. Plasmids were isolated using a QIAprep Spin Miniprep Kit (QIAGEN, Hilden, Germany), and the PCR products were purified with the QIAquick PCR Purification Kit (QIAGEN, Hilden, Germany). PCR reactions were performed in a (total volume of $50 \mu \mathrm{L}$ ) Mastercycler ep gradient S (Eppendorf, Hamburg, Germany). The recovered PCR fragments and plasmids were sequenced by Eurofins MWG Operon (Ebersberg, Germany). Plasmids were transformed into E. coli and P. pastoris using a Multiporator (Eppendorf, Hamburg, Germany), according to the supplier's protocol.

\section{Total RNA isolation}

To obtain the full-length cDNA of MCAP gene, total RNA was isolated from solid-state culture of the $M$. circinelloides as follows: $250 \mathrm{~mL}$ Erlenmeyer flasks containing $10 \mathrm{~g}$ of wheat bran moistened with $200 \mathrm{mM} \mathrm{HCl}$, up to a water content of $120 \%$ on a dry basis, and autoclaved at $121^{\circ} \mathrm{C}$ for $20 \mathrm{~min}$, were inoculated with $5 \times 10^{6}$ spores of $M$. circinelloides. Cultured for four days at $24^{\circ} \mathrm{C}$, $100 \mathrm{mg}$ of the mycelium were collected with tweezers and immediately used for total RNA extraction using the RNeasy Plant Mini Kit (QIAGEN, Hilden, Germany). The concentration and quality of the total RNA was determined by using the NanoDrop ND-1000 spectrophotometer (NanoDrop Technologies, Inc. Wilmington, Delaware, USA).

\section{First-strand cDNA synthesis, 5'-RACE cDNA and 3'-RACE CDNA}

Two microgram of total RNA were used for the synthesis of the first strand of 5'-RACE-Ready cDNA and 3'RACE-Ready cDNA. The synthesized first strand cDNA was used as a template for the $5^{\prime}$-RACE cDNA and $3^{\prime}$ RACE cDNA using the gene specific reverse primer GSP-Mucor-2R and forward primer GSP-Mucor-1 F, respectively (Table 2). In these cases, the conditions for PCR reactions were as described by Clontech (SMART RACE cDNA Amplification Kit User Manual). The amplified RACE fragments were separated by agarose gel electrophoresis and recovered using NucleoTrap Gel Extraction Trial Kit (Takara Europe-Clontech, Saint-Germainen-Laye, France). Using this technique, the sequences of the extreme ends of the MCAP gene ( $5^{\prime}$ and $3^{\prime}$ ) were obtained. Finally, the full-length cDNA sequence of the aspartic proteinase of M. circinelloides (deposited in GenBank

Table 2 Oligonucleotides used for PCR amplification in this study

\begin{tabular}{|c|c|}
\hline Primer name & Sequence $\left(5^{\prime}-3^{\prime}\right)$ \\
\hline \multicolumn{2}{|c|}{ Primers for DNA fragment PCR to obtain a partial sequence of genomic DNA of the acid proteinase } \\
\hline $12 \mathrm{ND}-\mathrm{F}$ & AACGATATCGAGTACTATGGT \\
\hline M.cir-2R & TTAAAGACTTCATAGTTGTTCTT \\
\hline \multicolumn{2}{|c|}{ Primer for 3'-RACE PCR (Gene-specific primer) } \\
\hline GSP-Mucor-1 F & GATGGTCGTGCCTGGTCTATCCAAT \\
\hline \multicolumn{2}{|c|}{ Primer for 5'-RACE PCR (gene-specific primer) } \\
\hline GSP-Mucor-2R & CATTGTCTCTGGCACCGTATTGAGCAGC \\
\hline \multicolumn{2}{|c|}{ Primers for full-length cDNA and recombinant plasmids } \\
\hline APMC-EcoNael-F & ATGGAATTCGCCGGCGCTACTACTGATGCCACTGGTACTGTCCCCG \\
\hline APMC-F & AGGAATTCTTCTCATTAGTCTCTTCTTG \\
\hline APMC-Met-F & ATGGAATTCATGAAATTCTCATTAGTCTCTTCTTGTGTC \\
\hline MCAP-3 F & TATCTCGAGaaaagaGCTCCCAGTGGTAGCAAGAA \\
\hline Xhol-N-MCAP-F & TATCTCGAGaaaagaATGAAATTCTCATTAGTCTCTTCTTGTG \\
\hline APMC-Notl-R & AAAGCGGCCGCGACAGATTTGGCAATTT \\
\hline APMC-Stop-R & GTGATTTATAGATAGATAGATGAAATGTACCAAA \\
\hline \multicolumn{2}{|c|}{ Primers to identify clones containing recombinant plasmids } \\
\hline pGAP-F & GTCCCTATTTCAATCAATTGAACAAC \\
\hline AOX1pGAP-Rev & CAAATGGCATTCTGACATCCTC \\
\hline
\end{tabular}

The underlined sequences (GAATTC; ECoRI, CTCGAG; Xhol and GCGGCCGC; Notl) represent the additional restriction sites at the $5^{\prime}$ ends of forward and reverse primers. The lowercase letters indicate the Kex2 cleavage sites. The primers (for First-strand CDNA synthesis, $3^{\prime}-$ RACE CDNA and 5'-RACE CDNA) provided in the SMART RACE CDNA Amplification Kit (Clontech) are not described in the table. 
under accession number JQ906105) was amplified from the $5^{\prime}$-RACE-Ready cDNA while the genomic MCAP of the aspartic proteinase (deposited in GenBank under accession number JQ906106) was amplified from genomic DNA of $M$. circinelloides using the forward primers APMC-Met-F and the reverse primer APMC-stop-R (Table 2).

The PCR reactions contained the following components each listed at their final concentrations: $1 \times$ Advantage 2 PCR Buffer, 200 pmol $\mu \mathrm{L}^{-1}$ dNTPs, 2 pmol $\mu \mathrm{L}^{-1}$ of each primer (forward and reverse), $2.5 \mu \mathrm{L}$ of $5^{\prime}$ first-strand cDNA (unknown concentration), $1 \times$ Advantage 2 Polymerase Mix (Clontech, Palo Alto, CA, USA). PCR was carried out at an annealing temperature of $61^{\circ} \mathrm{C}$.

\section{Amplification of the CDNA encoding MCAP}

To clone the full-length cDNA encoding MCAP in $M$. circinelloides, a partial sequence of genomic DNA of the acidic proteinase gene was first obtained. Non-specific primers (12 ND-F and M.cir-2R) (Table 2) were designed using the conserved motifs of aspartic proteinases from different species of filamentous fungi (Figure 1). In this case, the amino acid sequence of the Mucor bacilliformis proteinase [12] and those of Rhizopus microspores var. rhizopodiformis (accession number CAA72511), Rhizopus niveus (accession number Q03700), Rhizopus microspores var. chinensis (accession number AAB59306), Rhizopus microsporus var. chinensis (accession number AAA33881), Rhizopus microsporus var. chinensis (accession number AAA33879) and Syncephalastrum racemosum (accession number AAC69517) were downloaded from the GenBank and aligned with BLAST.
After PCR, a 956 bp fragment was obtained. PCR amplification was carried out at an annealing temperature of $52^{\circ} \mathrm{C}$ using $1.25 \mathrm{U} \mathrm{Taq}$ DNA polymerase and $200 \mathrm{ng}$ of genomic DNA. The deduced amino acid sequence of the product was aligned with the amino acid sequence of aspartic proteinase from $M$. bacilliformis [12], $R$. niveus (accession number X56992) and $R$. microsporus var. chinensis (accession number M63451) using BLAST algorithm. Since the fragment sequence showed high similarity to the selected proteinases, gene-specific primers were designed to perform 5'-RACE and 3'RACE as well as for the amplification of a full-length cDNA of the aspartic proteinase gene from the first strand 5 '-RACE-Ready cDNA of $M$. circinelloides by SMART $^{\text {mi }}$ RACE PCR Kit (Takara Europe-Clontech, Saint-Germain-en-Laye, France).

\section{Recombinant plasmids construction and codon usage adaptation}

A set of expression plasmids were constructed by cloning a partial MCAP, whole $M C A P$, or SyMCAP gene in frame with the alpha-factor $(\alpha-M F)$ secretion signal and the $C$ terminal polyhistidine tag (6x His tag) into the multiple cloning site of $\mathrm{pGAPZ} \alpha-\mathrm{A}$, indicating that all $M C A P$ products were cloned downstream of the glyceraldehyde3-phosphate dehydrogenase (GAP) promoter [13]. The whole $M C A P$ coding sequence (with intron sequence) was amplified from $M$. circinelloides genomic DNA while the full-length cDNA (without intron) or partial sequence cDNA (without signal peptide and without intron) encoding MCAP was amplified from the $5^{\prime}$ of the first strand cDNA. The final concentrations of components for PCR

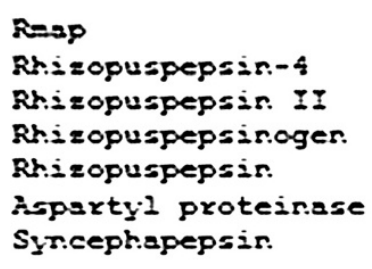

$R=a p$

Rr:izopuspepsin- -4

Rrizzopuspepsir. II

Rh:izopuspepsir.oger.

Rhizzopuspepsir.

$\lambda=p a x t y 2$ proteinase

Syrceptapepain
QSTGSVPVUDVGSDLEYYOVVTVGTP 90

ESSGSVPVTDDGIDIEYYCEVTVGTP 99

AGVGTVPMTDYGIDVEYYCOVTIGTP 94

AGVGTVPMTDYGIDIEYYCOVTIGTP $\$ 4$

AGVGTVPMTDYGIDVEYYCOVTIGTP 53

-GTGTVPVTDDGIDIEYYGTVKVGTP 25

SGTGSVPMTDVDYDVEYYATVSVGTP 98

$\ldots *: * *: \ldots,: \geq * * * * . * \ldots * * *$

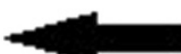

ILGDVELKATYVVINOQVPEVQIAPI 386

IFGDVELKATYVVERPQVPQVQIAPI 396

IIGDTFLKANYVVEROGVPEVIAPV 391

IIGDTE LKANYYVENOGVPEVOIAPV 392

IIGDTELKATYVVENQGVPEVIAPV 350

IVGDVELKANYVVEARRVPQVOIAK- 323

IIGDTELKANYVVENQCVPEVUIAPS 393

*,**,*********.,**;****.

Figure 1 Multiple alignment of the consensus motifs sequences NDIEYYG and FLKNNYVVFN of several fungal aspartic proteinases. Consensus motifs sequences are marked in black arrows. Asterisks indicate conserved amino acids. The number to the right of the amino acid sequence is based on the protein. 
of recombinant plasmids was: $1 \times$ ThermoPol reaction buffer, 200 pmol $\mu \mathrm{L}^{-1} \mathrm{dNTPs}, 2$ pmol $\mu \mathrm{L}^{-1}$ of each primer, 1 ng $\mu \mathrm{L}^{-1}$ plasmid DNA, 0.04 units $\mu \mathrm{L}^{-1} \mathrm{Taq}$ DNA polymerase. The first round of PCR amplification was carried out at $63^{\circ} \mathrm{C}$ for 5 cycles, and the second round of amplification was at $66^{\circ} \mathrm{C}$ for 25 cycles. To construct the plasmids pGAPZ $\alpha+$ MCAP, pGAPZ $\alpha+$ MCAP-2, pGAPZ $\alpha+$ MCAPSP1, pGAPZ $\alpha+$ MCAP-3 and pGAPZ $\alpha+$ MCAP-5, the PCR reactions were carried out using the following forward primers: APMC-F, APMC-Met-F, APMC-EcoNaeI-F, XhoIN-MCAP-F and MCAP-3 F, respectively. While the reverse primer APMC-NotI-R was used in all the PCR reactions (Table 2). The PCR products were purified as previously described and were digested using restriction enzymes for which specific sites had been previously added using primers. The digested PCR products were then ligated into the appropriate sites of the multiple cloning site of pGAPZ $\alpha-A$ using T4 DNA ligase. Additionally, original $M C A P$ was adapted to the optimal codon usage of $P$. pastoris and cloned in frame with DNA sequence for the $\mathrm{N}$-terminal $\alpha$ - factor signal sequence, under the GAP promoter (performed by MWG Operon, Ebersberg, Germany). The final plasmid construct was designated as pGAPZ $\alpha+$ SyMCAP-6. The ligated products were transformed into electrocompetent $E$. coli cells with further selection in LB-zeocin plates and expression was performed using P. pastoris $\mathrm{X}-33$.

\section{Transformation of recombinant plasmids containing $M C A P$ gene into $P$. pastoris}

To examine the expression of MCAP constructs in P. pastoris under the control of GAP promoter, recombinant plasmids were digested by AvrII restriction enzyme and transformed into P. pastoris competent cells (Invitrogen, Darmstadt, Germany). Eighty microlitres of $P$. pastoris cells were mixed with $2.5 \mu \mathrm{g}$ of linearized recombinant plasmids. The transformation mixture $(100 \mu \mathrm{L})$ was plated on YPD agar plates supplemented with zeocin $\left(100 \mu \mathrm{g} \mathrm{mL}^{-1}\right)$ and incubated at $30^{\circ} \mathrm{C}$ for 4 days. In order to confirm that $P$. pastoris contained the recombinant plasmid, PCR and sequence analysis were performed as previously described.

\section{Production of crude extracellular MCAP}

For the production of MCAP in P. pastoris, starter cultures of single colonies of transformants were grown in $25 \mathrm{~mL}$ YPD media in $100 \mathrm{~mL}$ shake flasks for $20 \mathrm{~h}$ at $30^{\circ} \mathrm{C}$. The cultures were inoculated in triplicate in $75 \mathrm{~mL}$ YPD in $250 \mathrm{~mL}$ shake flasks to a starting $\mathrm{OD}_{600}$ of 0.1. Cultivation was carried out for 4 days. Considering that glucose concentrations above $40 \mathrm{~g} \mathrm{~L}^{-1}$ did not show any increase in MCAP activity, enzyme expression was performed in 20 and $40 \mathrm{~g} \mathrm{~L}^{-1}$ glucose and adjusted to an initial $\mathrm{pH}$ of 5.0 and 7 with citric acid. In order to analyze the effect of temperature in the culture medium on MCAP expression, recombinants were grown at $23,24,25,27$ and $30^{\circ} \mathrm{C}$, at initial $\mathrm{pH}$ of 5.0. The supernatant from cultures was taken every $24 \mathrm{~h}$ and cells were harvested by centrifugation at $4000 \mathrm{~g}$ at $4^{\circ} \mathrm{C}$. Thereafter, milk clotting enzyme activity was analyzed in the supernatant broths. The supernatant culture from wild type $P$. pastoris was used as a negative control.

To analyse MCAP production by M. circinelloides, 6 day cultivation was performed in solid-state reactor. The crude extract was obtained according to the method of Areces and coworker [7] and assayed daily in duplicate. The obtained protein was considered as a control reference MCAP.

\section{Protein determination}

The amount of protein in the crude extract, supernatant broth, as well in the chromatographic fractions was determined according to the Bradford procedure [14] and bovine serum albumin served as a standard (Fischer Scientific, Schwerte, Germany).

\section{Chromatographic analysis of MCAP}

All chromatographic experiments were done using an ÄKTA purifier system (GE Healthcare, Munich, Germany). After removal of the cells by centrifugation at $4000 \mathrm{~g}, 4^{\circ} \mathrm{C}$, he MCAP recombinant protein was purified from the supernatant by cation-exchange chromatography using a $5 \mathrm{~mL}$ HiTrap SP FF column attached to the ÄKTA purifier. The protein extract was adjusted to $\mathrm{pH} 3.1$ using citric acid, and then a range of $37-48 \mathrm{~mL}$ of the mixture was injected to the previously equilibrated column with $50 \mathrm{mM}$ citric acid buffer pH 3.5 and $75 \mathrm{mM} \mathrm{NaCl}$. After washing with the same buffer and $75 \mathrm{mM} \mathrm{NaCl}$, the elution was performed with the same buffer and $200 \mathrm{mM}$ $\mathrm{NaCl}$ and step gradient was developed in 5 column volumes with a flow rate of $1 \mathrm{~mL} \mathrm{~min}{ }^{-1}$. For protein content and milk clotting assays, $2.5 \mathrm{~mL}$ of chromatographic fractions were collected and analyzed.

\section{SDS-PAGE analysis}

The crude extracellular supernatant proteins were desalted using a PD-10 column (GE Healthcare, Munich, Germany) equilibrated with $20 \mathrm{mM}$ phosphate buffer at $\mathrm{pH}$ 7.2. These recombinant products were about 10 times concentrated at room temperature using Vacuum Concentrator 5305 (Eppendorf, Hamburg, Germany) and applied to a $12.5 \%$ SDS-PAGE. Purified enzyme and crude control reference MCAP were loaded directly into the SDS-PAGE gel and stained with Coomassie Brilliant Blue.

\section{Milk clotting assay}

The milk clotting activity was analyzed according to the method of Arima and coworkers, with some modifications [15]. Initially, $1 \mathrm{~mL}$ of substrate made of $100 \mathrm{~g} \mathrm{~L}^{-1}$ 
skimmed milk powder and $10 \mathrm{mM} \mathrm{CaCl}$ in distilled water was added to a $10 \mathrm{~mL}$ test tube and the contents were incubated at $35^{\circ} \mathrm{C}$ for $10 \mathrm{~min}$. Afterwards, $0.1 \mathrm{~mL}$ of enzyme sample was added to the pre-incubated substrate. One milk clotting unit (MCU) was defined as the enzyme amount which clotted $1 \mathrm{~mL}$ of the substrate within $40 \mathrm{~min}$ at $35^{\circ} \mathrm{C}$ [15]. Based on this definition, the clotting activity was calculated according to equation of Rao and coworker [16], (Equation 1).

$$
\mathrm{MCU} \mathrm{mL}^{-1}=2400 /(\mathrm{t} . \mathrm{E})
$$

where 2400 is the conversion of $40 \mathrm{~min}$ to $\mathrm{s}$, t; clotting time (s) and $\mathrm{E}$; the enzyme volume $(\mathrm{mL})$.

\section{Deglycosylation assay}

About $35 \mu \mathrm{g}$ of crude extracellular protein from the recombinant X-33/pGAPZ $\alpha+$ MCAP-5 cultivated in YPD medium at initial $\mathrm{pH}$ of 5.0 was digested with 2 units of endoglycosidase $\mathrm{H}$ (endo $\mathrm{H}$ ) (New England Biolabs, Frankfurt, Germany) at $37^{\circ} \mathrm{C}$ for $2 \mathrm{~h}$. The crude protein had previously been desalted using a PD-10 column and equilibrated with $20 \mathrm{mM}$ phosphate buffer, $\mathrm{pH}$ 6.0.

\section{Proteolytic activity assay}

Proteolytic activities (PA) of obtained chromatographic fractions were measured by the method of Fan and coworkers using $\mathrm{N}, \mathrm{N}$-dimethylcasein (DCM) as the substrate [17]. For the assay, $10 \mathrm{mg}$ of DCM was dissolved in $1 \mathrm{~mL}$ of $20 \mathrm{mM}$ phosphate buffer, $\mathrm{pH}$ 5.8. Subsequently, $45 \mu \mathrm{L}$ of the solution was thoroughly mixed with $45 \mu \mathrm{L}$ of enzyme sample and incubated at $35^{\circ} \mathrm{C}$ for 30 minutes. The reaction was stopped using $1.35 \mathrm{~mL}$ of $10 \%$ ice-cold trichloroacetic acid (TCA). The reaction sample was kept on ice for $30 \mathrm{~min}$ and later centrifuged at $15000 \mathrm{~g}$ for $15 \mathrm{~min}$. The absorbance of the mixture was measured at $280 \mathrm{~nm}$. To make the reference solution, TCA was added before the enzyme. One unit of proteolytic activity $\left(\mathrm{U} \mathrm{mL}^{-1}\right)$ was defined as the amount in microgram of tyrosine released from DCM per minute at $35^{\circ} \mathrm{C}$. The extinction for tyrosine was taken as



$$
\begin{aligned}
\mathrm{PA}((\mathrm{U} / \mathrm{ml})= & \left(\mathrm{A}_{280 \mathrm{~nm}} / 0.005\right) \times 1.44 \mathrm{~V} \\
& \times(1 / 30) \times 1000 / 45)
\end{aligned}
$$

where $\mathrm{V}$ is volume in $\mathrm{mL}$.

\section{Results and discussion}

\section{Isolation of the partial MCAP gene}

The gene encoding MCAP was amplified by PCR from M. circinelloides strain DSM 2183. A 959 bp fragment was amplified using primers designed based on homology against NDIEYYG and KNNYVVFN consensus motifs from aspartic proteinase of various species of filamentous fungi (Figure 1). The deduced amino acid sequence of the obtained 959 bp fragment indicated the presence of catalytic Asp residues found in most known aspartic proteinases. In aspartic proteinases, the catalytic Asp residues is found within the motif Asp-Xaa-Gly in which Xaa can be either Ser or Thr [18].

\section{Cloning and gene comparison of the CDNA encoding the acidic proteinase}

After obtaining the partial DNA sequence of $M C A P$, specific primers were designed for the amplification of $3^{\prime}$-RACE and 5'-RACE of aspartic proteinase gene from the first-strand cDNA of $M$. circinelloides by SMART ${ }^{\mathrm{m}}$ RACE PCR. The full-length cDNA of the aspartic proteinase from $M$. circinelloides was amplified from the $5^{\prime}$ first-strand, while the full-length MCAP encoding the aspartic proteinase was amplified from genomic DNA of M. circinelloides.

By comparing the nucleotide sequence of aspartic proteinase amplified from the 5 'first-strand cDNA with the sequence amplified from the genomic DNA of $M$. circinelloides, we found that the whole MCAP has an intron of 63 bp long and encodes 394 amino acid residues (Figure 2). The amino acid sequence of $M$. circinelloides MCAP was further aligned with the $M$. bacilliformis [12] sequence and with non-redundant protein database using BLASTX 2.2.24. The highest similarity between the MCAP amino acid sequence and a $M$. bacilliformis homolog was found to be $88 \%$ identity. The identity with $R$. oryzae (accession number ACL68088), $R$. microsporus (accession number CAA72511), R. microsporus var. chinensis (accession number AAB59305), $R$. niveus (accession number CAA40284), and S. racemosum (accession number AAC69517) was 66, $65,64,63$, and $59 \%$, respectively.

\section{Signal peptide sequence and $\mathrm{N}$-glycosylation site}

The analysis of the amino acid sequence by a SignalP 3.0 server identified a cleavage signal sequence site between positions Ala21 and Ala22 in the MCAP protein (http:// www.cbs.dtu.dk/services/SignalP/). The putative signal peptide corresponding to the first 21 amino acids; MKFSLVSSCVALVVMTLAVDA, shows features of signal peptides, such as a highly hydrophobic region. Additionally, by using the NetNGlyc v1.0 server (Center for Biological Sequence Analysis, Technical University of Denmark DTU), one potential N-glycosylation site; Asn-X-Ser/Thr, was found to be at positions Asn331 in the MCAP (Figure 2).

\section{Protein expression, purification and SDS-PAGE analysis}

To analyze the expression of MCAP gene in P. pastoris, a set of recombinant plasmids carrying either the partial or the whole $M C A P$ gene, was cloned into the $P$. pastoris expression vector $\mathrm{pGAPZ} \alpha-\mathrm{A}$. The secreted MCAP 


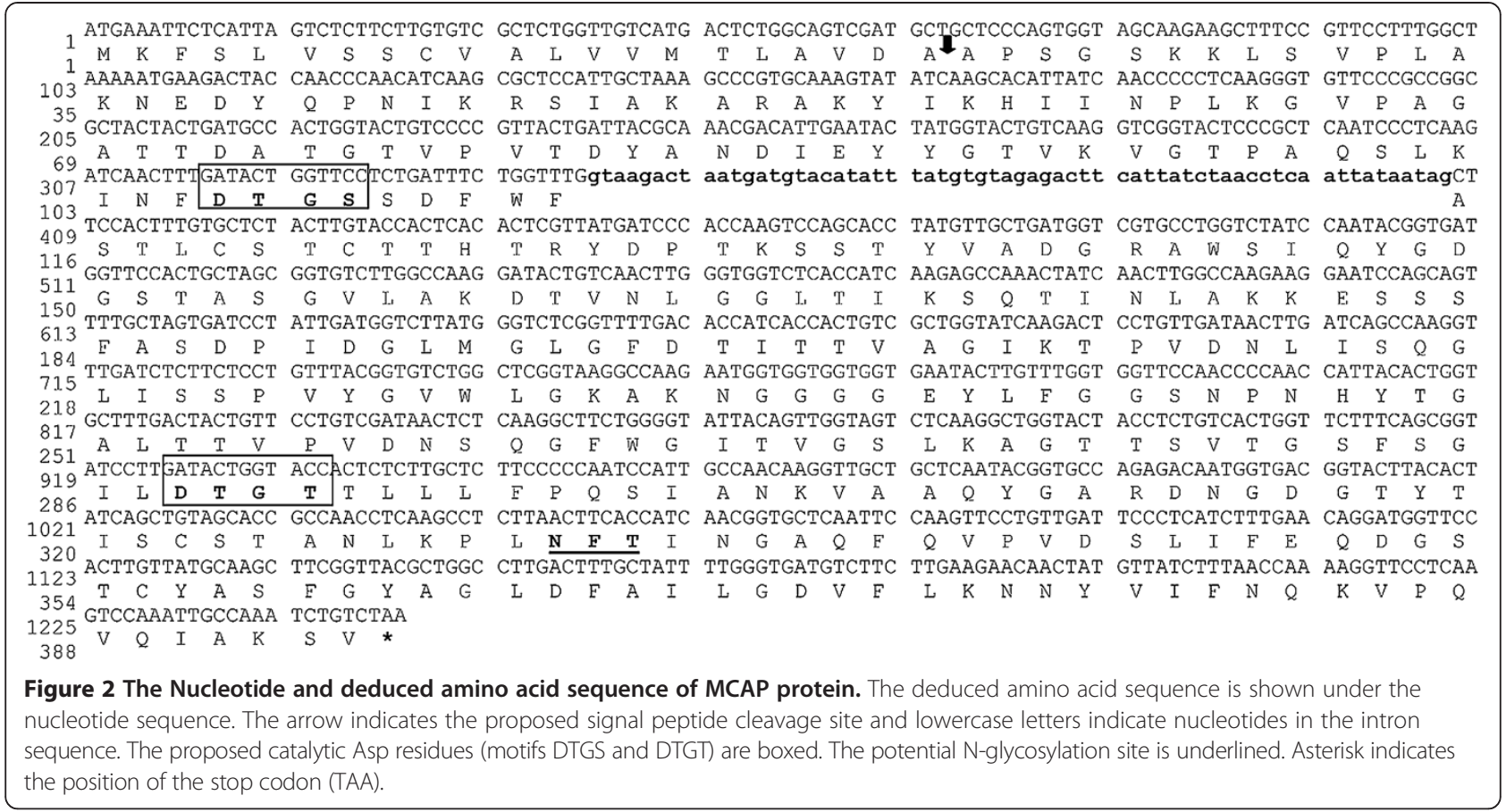

forms were separated by SDS-PAGE. The analysis showed that the recombinant yeast X-33/pGAPZ $\alpha+\mathrm{M}$ CAP-5 expressed two forms of MCAP when cultivated in YPD medium at pH 5.0 (Figure 3, lane 2, Figures 4A and 5) as well as the recombinant yeast X-33/pGAPZ $\alpha+-$ SyMCAP-6 (Figures 4B, and 5, lanes, 6 and 7). The molecular mass of the largest protein was $37 \mathrm{kDa}$ while that of the smallest protein was $33 \mathrm{kDa}$. Both proteins seem to have $2.5 \mathrm{kDa}$ of the additional amino acids of the Cterminal polyhistidine tag since the molecular mass was distinctly higher than $30 \mathrm{kDa}$ of the single MCAP from M. circinelloides (Figure 3, lane 7). It was confirmed that, MCAP was expressed in two forms; one glycosylated and the other non-glycosylated. Incubation of the MCAP with endo $\mathrm{H}$ resulted in the decrease in the apparent molecular weight (Figure 4A), giving values identical to those of the authentic MCAP from $M$. circinelloides.

None of the other recombinants analyzed in this study was able to produce MCAP. It is possible that $P$. pastoris containing plasmid pGAPZ $\alpha+\mathrm{MCAP}$ (data not shown) was unable to cleave the $M C A P$ gene intron sequence. Such a situation has been shown in $S$. cerevisiae that did not secrete $R$. niveus aspartic proteinase as it contained an intron sequence [19]. In the case of strain containing pGAPZ $\alpha+\mathrm{MCAP}-2$ and pGAPZ $\alpha+\mathrm{MCAP}-3$ (Figure 3, lanes 4,5 , respectively), the start codon of $\alpha$-MF secretion signal and start codon of MCAP are each very close to the promoter, which might have caused some inhibition of transcription. The unsuccessful result of X-33/ pGAPZ $\alpha+$ MCAP-SP (Figure 3, lanes 6) could have been due to the deleted part of MCAP proenzyme sequence,

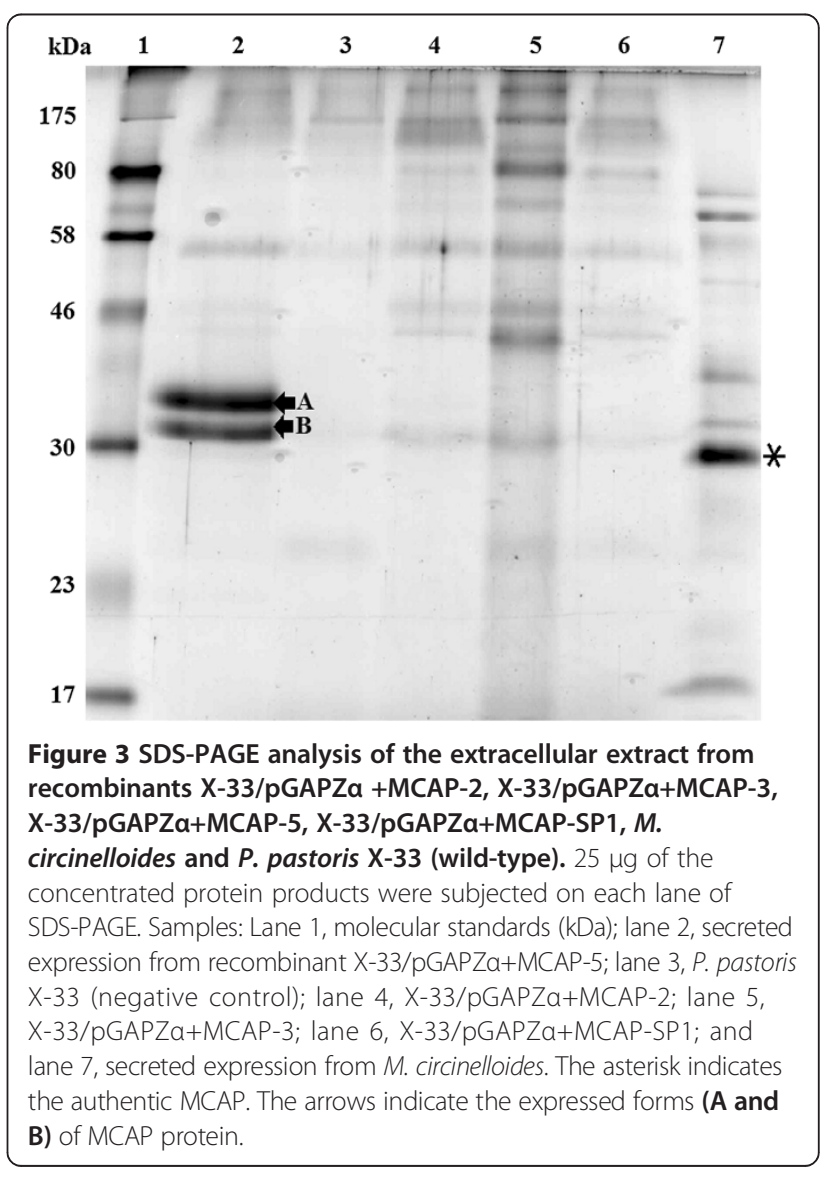




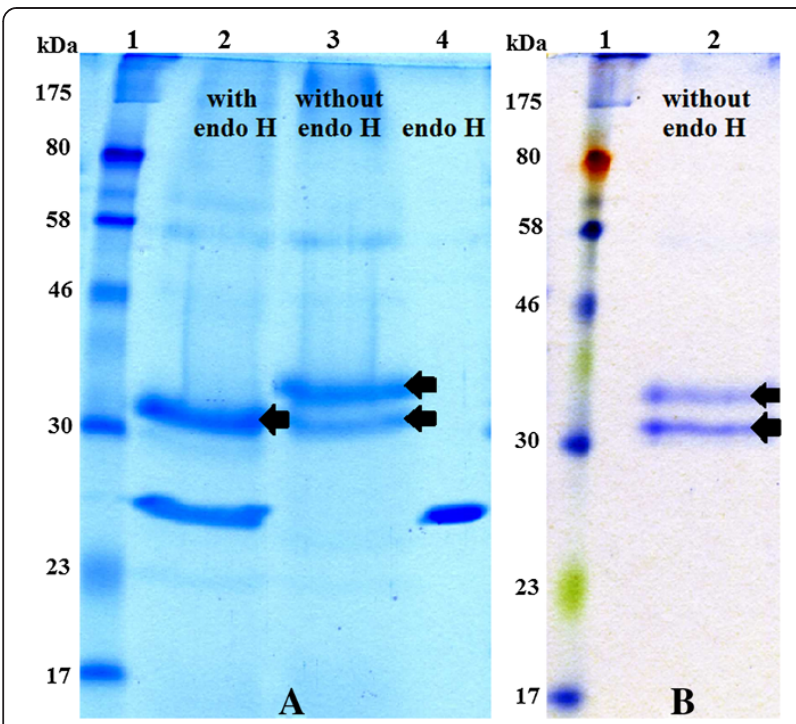

Figure 4 SDS-PAGE electrophoretic pattern comparisons of recombinant $P$. pastoris. (A) Enzymatic analysis of the MCAP protein with endoglycosidase (Endo $\mathrm{H}$ ). $25 \mu \mathrm{g}$ of the protein products were digested with endo $\mathrm{H}$ and subjected to SDS-PAGE. Lane 1, molecular standards; lane 2, secreted expression from X-33/ pGAPZa+MCAP-5 (digested); lane 3, secreted expression from X-33/ pGAPZa+MCAP-5 (undigested); lane 4, endo $\mathrm{H}$. The arrows indicate the expressed forms of MCAP protein (above N-glycosylated protein, below the deglycosylated protein, respectively). (B) Analysis of the purified MCAP protein on HiTrap SP Sepharose Fast Flow. Lane 1, molecular standards; lane 2, $10 \mu \mathrm{g}$ of secreted expression from recombinant X-33/pGAPZa+SyMCAP-6. The arrows indicate the expressed forms of MCAP protein (above N-glycosylated protein, below the deglycosylated protein, respectively).

which is very important for its conversion to the mature form.

\section{Effect of glucose concentration, temperature and initial pH on MCAP production \\ Glucose concentration}

The activity of the MCAP produced by the recombinant $\mathrm{X}-33 / \mathrm{pGAPZ} \alpha+\mathrm{MCAP}-5$ grown in two concentrations of glucose as the sole carbon source in the YPD medium at $\mathrm{pH} 5.0$ and $24^{\circ} \mathrm{C}$ was compared. When glucose was used at $20 \mathrm{~g} \mathrm{~L}^{-1}$ the relative activity of MCAP decreased to $40 \%$ compared to a glucose concentration of $40 \mathrm{~g} \mathrm{~L}^{-1}$. The time course of MCAP production by X-33/pGAP$\mathrm{Z} \alpha+\mathrm{MCAP}-5$ (Figures 5 and $6 \mathrm{~A}$ ) showed that after 24, 48,72 and $96 \mathrm{~h}$ of growth the activity of the crude enzyme was $13\left(7 \mathrm{mg} \mathrm{L}^{-1}\right), 172\left(54 \mathrm{mg} \mathrm{L}^{-1}\right), 257\left(110 \mathrm{mg} \mathrm{L}^{-1}\right)$ and $181 \mathrm{MCU} \mathrm{mL}^{-1}$ (100 $\left.\mathrm{mg} \mathrm{L}^{-1}\right)$, respectively. Therefore, it was concluded that the maximum enzyme activity of 257 MCU mL- ${ }^{1}$ of fermentation broth was after approximately $72 \mathrm{~h}$ of cultivation when culture cells were in their late exponential growth phase and decreased after $96 \mathrm{~h}$ when the cells reached the stationary phase. The increase in activity was due to the quality of enzyme produced (Figures 5 and

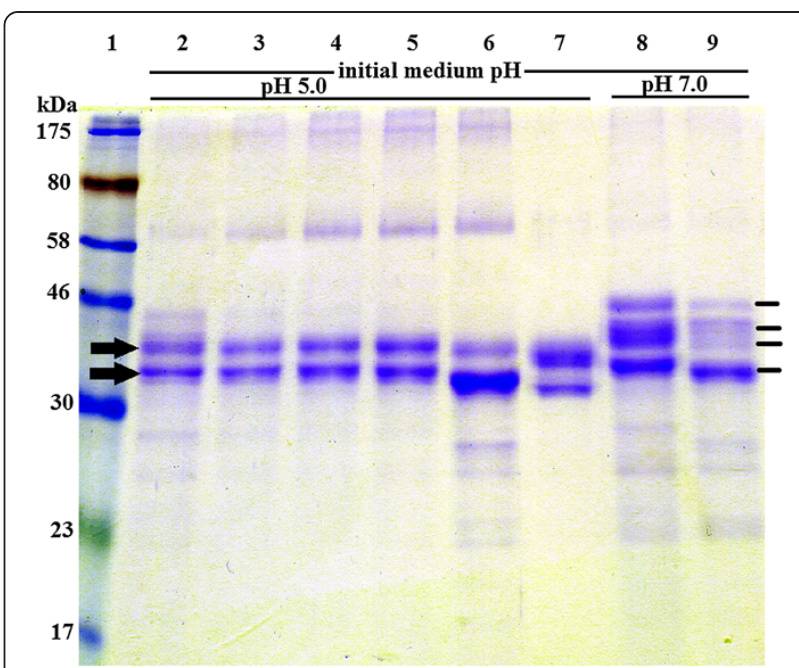

Figure 5 Kinetics and forms of MCAP secreted by recombinant X-33/pGAPZa+MCAP-5 and X-33/pGAPZa+SyMCAP-6.

Recombinants were cultured for 24, 48, 72 and 96 hours in YPD medium (initial medium pH: 5.0 and 7.0 ) at $24^{\circ} \mathrm{C}$. Proteins in the sample corresponding to $37 \mu \mathrm{L}$ of the original supernatant broth were loaded on each lane of SDS-PAGE. Samples: Lane 1, molecular standards ( $\mathrm{kDa}$ ); lanes 2, 3, 4, 5, and 8, secreted expression from recombinant X-33/pGAPZa+MCAP-5 (lane 2, 24 h; lane 3, 48 h; lane 4, $72 \mathrm{~h}$; lane 5, $96 \mathrm{~h}$; lane 8, $72 \mathrm{~h}$ ); lanes 6, 7, and 9, secreted expression from recombinant X-33/pGAPZa+SyMCAP-6 after 72 hours of cultivation. Lane 7,4 $\mu \mathrm{g}$ of purified MCAP protein on HiTrap SP Sepharose Fast Flow. The arrows indicate the expressed forms of MCAP protein when the initial pH value of the medium was 5.0 and the lines indicate the expressed forms of MCAP at initial pH of 7.0.

6A). Furthermore, when the original MCAP gene was adapted to the optimal codon usage of $P$. pastoris, the expression of aspartic proteinase in P. pastoris (X-33/pGAP$\mathrm{Z} \alpha+$ SyMCAP- 6 ) increased by nearly $40 \%$. The amount of MCAP produced after $72 \mathrm{~h}$ of cultivation was $186 \mathrm{mg} \mathrm{L}^{-1}$ and the maximum enzyme activity was $580 \mathrm{MCU}$. The amount of MCAP in the culture supernatant was estimated as the difference between the calculated proteins produced from the recombinant $P$. pastoris and wild-type $P$. pastoris, as well as by considering the band intensities on SDS-PAGE.

\section{Effect of temperature}

The recombinant $P$. pastoris with the original MCAP gene was grown for $72 \mathrm{~h}$ at $23,24,25,27$ and $30^{\circ} \mathrm{C}$ and the enzyme activity of $178,260,248,224$ and $145 \mathrm{MCU} \mathrm{mL}^{-1}$, was obtained, respectively. Temperature seemed to affect MCAP expression in $P$. pastoris and the optimum temperature for the MCAP production by X-33/pGAP$\mathrm{Z} \alpha+\mathrm{MCAP}-5$ was found to be $24^{\circ} \mathrm{C}$ (Figure $6 \mathrm{~B}$ ).

\section{Effect of $\mathrm{pH}$}

The effect of $\mathrm{pH}$ on the activity of the recombinant enzyme produced in the culture medium incubated at $24^{\circ} \mathrm{C}$ 

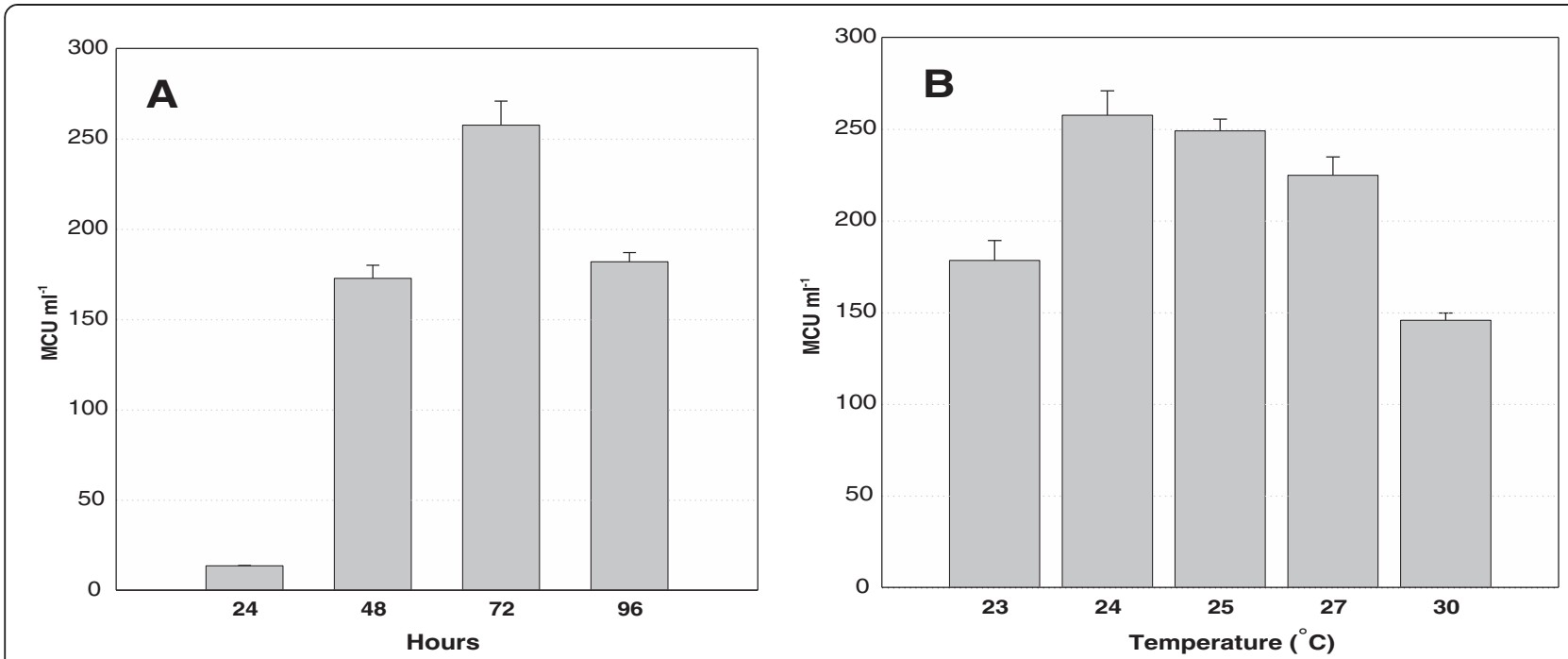

Figure 6 Extracellular production of MCAP from recombinant $P$. pastoris X-33/pGAPZa+MCAP-5. A) Time course in YPD medium containing $4 \%$ glucose at $24^{\circ} \mathrm{C}$. B) Production of aspartic proteinase after 72 hours in YPD medium containing $4 \%$ glucose. The values shown are the mean activity with standard deviation obtained from three sets of experiments.

for 4 days and supplemented with $40 \mathrm{~g} \mathrm{~L}^{-1}$ glucose was investigated. When the initial $\mathrm{pH}$ of the culture medium was 7 instead of 5 , the relative enzyme activity was reduced to $55.6 \%$ while the levels of protein expressed decreased only by $5 \%$. Additionally, regardless of the temperature, X-33/pGAPZ $\alpha+$ MCAP-5 and X-33/pGAP$\mathrm{Z} \alpha+$ SyMCAP- 6 produced four forms of the recombinant protein with molecular weights of $44,40,37$ and $33 \mathrm{kDa}$ when the initial $\mathrm{pH}$ value of the medium was 7 (Figure 5). After the cultivation period the $\mathrm{pH}$ of the cultivation media decreased from 7 to 6.3 thus confirming previous observations made for Mucor sp. Rennin. The model for the processing of prepro-MPR, a zymogen of Mucor sp. Rennin expressed in S. cerevisiae, where it was demonstrated that prepro-MPR matured under the acidic $\mathrm{pH}$ [20]. This suggests that the MCAP forms of 44 and $40 \mathrm{kDa}$ were also glycosylated and inactive. However, they were converted to the mature proteins with a molecular weight of 37 and $33 \mathrm{kDa}$ at $\mathrm{pH} 5.0$.

\section{Characterization of MCAP}

\section{Optimum $\mathrm{pH}$}

The MCAP proteins were tested for milk clotting activity at various $\mathrm{pH}$ values. The maximum activity in all proteins was observed at $\mathrm{pH}$ 3.6. At $\mathrm{pH} 7.0$ the activity decreased

Table 3 Characteristics of the purified recombinant aspartic proteinase (MCAP)

\begin{tabular}{cccc}
\hline $\begin{array}{c}\text { Molecular mass* } \\
(\mathbf{k D a})\end{array}$ & $\begin{array}{c}\text { Optimum } \\
\text { temperature }\left({ }^{\circ} \mathbf{C}\right)\end{array}$ & $\begin{array}{c}\text { Optimum } \\
\mathbf{~ p H}\end{array}$ & $\begin{array}{c}\text { Thermostability } \\
{ }^{* *}(\%)\end{array}$ \\
\hline $33 \& 37$ & 60 & 3.6 & 40 \\
\hline
\end{tabular}

*Enzyme having $(2.5 \mathrm{kDa})$ the additional amino acids of the C-terminal polyhistidine tag.

**Thermal stability of the enzymes at $55^{\circ} \mathrm{C}$, for $30 \mathrm{~min}$. drastically and the damage was irreversible. For this result, the histidine-tagged recombinant protein (MCAP) was not purified by affinity chromatography on immobilized metal (IMAC).

\section{Optimum temperature and thermal stability}

The MCAP activity was determined as a function of temperature from 35 to $65^{\circ} \mathrm{C}$. It was found that the activity was highest at $60^{\circ} \mathrm{C}$ regardless of protein type. In some cases, activity began to decrease at temperatures above $50^{\circ} \mathrm{C}$. For this reason, thermostability was tested by incubating the enzyme samples at temperatures ranging from 55 to $60^{\circ} \mathrm{C}$. The non-purified MCAPs retained $75 \%$ of their activity at $55^{\circ} \mathrm{C}$ and $40-60 \%$ of its activity was retained at $60^{\circ} \mathrm{C}$ after 60 min incubation at $\mathrm{pH} 3.6$ (Table 3). Also, it was found that the purified MCAP could not retain much activity compared to the nonpurified protein. Purified MCAPs retained less than $40 \%$ of their enzyme activity at $55^{\circ} \mathrm{C}$ after $30 \mathrm{~min}$ incubation at $\mathrm{pH} 3.6$ while the commercial preparation of $R$. miehe $i$ showed $85 \%$ of residual activity under the same conditions. Therefore, the purified MCAPs have a remarkable difference in thermal stability in comparison to the commercial protease from $R$. miehei. The enzymes that are sensitive to heat treatment are considered suitable

Table 4 Clotting and proteolytic activities of $\boldsymbol{P}$. pastoris and $\boldsymbol{R}$. miehei aspartic protease

\begin{tabular}{llll}
\hline Sample & $\begin{array}{l}\text { Milk clotting activity } \\
\text { MCA }(\mathbf{U} / \mathbf{\mu g})\end{array}$ & $\begin{array}{l}\text { Proteolytic activity } \\
\text { PA (U/ } / \mathbf{\mu g})\end{array}$ & Ratio MCA/PA \\
\hline MCAP & 137 & $7.02 \pm 0.28$ & $19.5 \pm 0.79$ \\
R. miehei & 311 & $11.11 \pm 0.27$ & $28.0 \pm 0.68$ \\
\hline
\end{tabular}

Results shown are the means of three sets of experiments. 
for milk clotting and for that reason; MCAP is a potential alternative for industrial utilization.

\section{Proteolytic activity of purified MCAP}

The ratio of milk clotting activity to proteolytic activity (MCA/PA) of MCAP was compared to the value observed for commercial rennet preparation. The higher the MCA/ PA ratio the more desirable the enzyme is during cheese making. Table 4 shows the MCAP ratio of about 20, which is below the calculated ratio for chymosin preparation.

\section{Conclusion}

The expression of MCAP under the control of the constitutive GAP promoter was investigated. $P$. pastoris was shown to be a good host for the production of MCAP protein and the novel MCAP was efficiently secreted into the medium to concentrations exceeding $180 \mathrm{mg} \mathrm{L}^{-1}$. Similar results were obtained by Yamashita and coworkers who cloned the M. pusillus Rennin gene in S. cerevisiae cells [21]. P. pastoris secreted two forms of MCAPs where one form was glycosylated while the other was nonglycosylated and similar to the authentic aspartic proteinase of the $M$. circinelloides. The observation was correlated to the presence of an N-glycosylation site Asn-PheThr at position Asn331 of the amino acid sequence of MCAP. Previous reports show that aspartic proteinases expressed in S. cerevisiae [21,22] and Aspergillus nidulans were secreted as single protein bands and in most cases glycosylated [23]. However, previous observations have shown that a mutant strain defective in $\mathrm{N}$-glycosylation process of $M$. pusillus excreted three glycoforms of $M$. pusillus proteins [24]. P. pastoris strain SMD1168 transformed with pGAPZ $\alpha+$ MCAP- 5 also excreted two forms of MCAPs (unpublished data). Interestingly, the MCAP protein contains the sequon located towards the Cterminus (Asn331 according to the MCAP of 394 amino acid residues). Therefore, $P$. pastoris can possibly excrete two forms of MCAPs. Results obtained by ShakinEshleman et al., suggest that a particular amino acid at the $\mathrm{X}$ position of an Asn-X-Ser sequon is critical for CoreGlycosylation Efficiency (CGE) [25]. They found that the substitution of the amino acid $\mathrm{X}$ with Phe, increases the efficiency of core glycosylation. In fact, MCAP contains Phe at the $\mathrm{X}$ position of the sequon. The result showed that the density of the band representing glycosylated recombinant protein was more intense than the recombinant non-glycosylated protein.

To elucidate the origin of the two types of proteins, mutations could be generated at the Asn-X-Ser sequon of MCAP.

\section{Nucleotide sequence accession numbers}

The sequences for MCAP determined in this article have been submitted to GenBank under accession numbers JQ906105 and JQ906106.
Competing interests

Authors declare that they have no competing of interests.

\section{Authors' contributions}

JAGS, MK and MFL have designed the work. JAGS carried out the experiment. JAGS, MK and MFL analyzed the data and contributed for the statistical analysis. JAGS, MK and MFL wrote the manuscript and reviewed the manuscript critically. All the authors have read the article and approved the final manuscript.

\section{Acknowledgments}

Partial support for this study was provided from Project PGSYS-EXCHANGE EU-PIRSES\#269211, ERA Net Euro TransBio-3, PGYSYS and Jacobs University Bremen.

Received: 11 August 2013 Accepted: 4 November 2013

Published: 9 November 2013

\section{References}

1. Hutkins RW: Cheese. In Microbiology and Technology of Fermented Foods. 1st edition. lowa: Blackwell Publishing; 2006:145-205.

2. Kumar A, Grover S, Sharma J, Batish VK: Chymosin and other milk coagulants: sources and biotechnological interventions. Crit Rev Biotechnol 2010, 30(4):243-258.

3. Poza M, Prieto-Alcedo M, Sieiro C, Villa TG: Cloning and expression of clt genes encoding milk-clotting proteases from Myxococcus xanthus 422. App Environ Microbiol 2004, 70(10):6337-6341.

4. Rogelj I, Perko B, Francky A, Penca V, Pungercar J: Recombinant lamb chymosin as an alternative coagulating enzyme in cheese production. J Dairy Sci 2001, 84(5):1020-1026.

5. Li J, Chi Z, Wang X: Cloning of the SAP6 gene of Metschnikowia reukaufii and its heterologous expression and characterization in Escherichia coli. Microbiol Res 2010, 165(3):173-182.

6. Claverie-Martln F, Vega-Hernàndez M: Aspartic proteases used in cheese making. In Industrial Enzymes. Edited by Polaina J, MacCabe A. Netherlands: Springer; 2007:207-219.

7. Areces LB, Bonino MB, Parry MA, Fraile ER, Fernandez HM, Cascone O: Purification and characterization of a milk clotting protease from Mucor bacilliformis. App Biochem Biotechnol 1992, 37(3):283-294.

8. Bernardinelli SE, Bottaro Castilla HR, Waehner RS, Muse J, Fraile ER: [Production and properties of the milk-clotting enzyme]. Revista Argentina de microbiologia 1983, 15(2):95-104.

9. Fernandez-Lahore HM, Auday RM, Fraile ER, Biscoglio De Jimenez Bonino M, Pirpignani L, Machalinski C, Cascone O: Purification and characterization of an acid proteinase from mesophilic Mucor sp. solid-state cultures. $J$ Peptide Res Off J Am Peptide Soc 1999, 53(6):599-605.

10. Grant SG, Jessee J, Bloom FR, Hanahan D: Differential plasmid rescue from transgenic mouse DNAs into Escherichia coli methylation-restriction mutants. Proc Natl Acad Sci USA 1990, 87(12):4645-4649.

11. Moore E, Arnscheidt A, Kruger A, Strompl CMM: Simplified protocols for the preparation of genomic DNA from bacterial cultures. In Molecular microbial ecology manua, Volume 1.6.1. Edited by Akkermans ADL, van Elsas JD, de Bruijn FJ. Dordrecht, The Netherlands: Kluwer Academic Publishers; 1999:1-15.

12. Machalinski C, Pirpignani ML, Marino C, Mantegazza A, de Jimenez Bonino MB: Structural aspects of the Mucor bacilliformis proteinase, a new member of the aspartyl-proteinase family. J Biotechnol 2006, 123(4):443-452.

13. Waterham HR, Digan ME, Koutz PJ, Lair SV, Cregg JM: Isolation of the Pichia pastoris glyceraldehyde-3-phosphate dehydrogenase gene and regulation and use of its promoter. Gene 1997, 186(1):37-44.

14. Bradford MM: A rapid and sensitive method for the quantitation of microgram quantities of protein utilizing the principle of protein-dye binding. Analytical Biochem 1976, 72:248-254.

15. Arima K, Yu J, Iwasaki S, Tamura G: Milk-clotting enzyme from microorganisms: V. Purification and crystallization of mucor rennin from mucor pusillus var. Lindt. App Microbiol 1968, 16(11):1727-1733.

16. Rao S, Mizutani O, Hirano T, Masaki K, Lefuji H: Purification and characterization of a novel aspartic protease from basidiomycetous yeast Cryptococcus sp. S-2. J Biosci Bioengineer 2011, 112(5):441-446. 
17. Fan T, Wang J, Yuan W, Zhong Q, Shi Y, Cong R: Purification and characterization of hatching enzyme from brine shrimp Artemia salina. Acta biochimica et biophysica Sinica 2010, 42(2):165-171.

18. Rao MB, Tanksale AM, Ghatge MS, Deshpande W: Molecular and biotechnological aspects of microbial proteases. Microbiol Mole Biol Rev MMBR 1998, 62(3):597-635.

19. Horiuchi H, Yanai K, Okazaki T, Takagi M, Yano K: Isolation and sequencing of a genomic clone encoding aspartic proteinase of Rhizopus niveus. J Bacteriol 1988, 170(1):272-278

20. Hiramatsu R, Aikawa J, Horinouchi S, Beppu T: Secretion by yeast of the zymogen form of Mucor rennin, an aspartic proteinase of Mucor pusillus, and its conversion to the mature form. J Biol Chem 1989, 264(28):16862-16866.

21. Yamashita T, Tonouchi N, Uozumi T, Beppu T: Secretion of Mucor rennin, a fungal aspartic protease of Mucor pusillus, by recombinant yeast cells. Mole Gen Genetics MGG 1987, 210(3):462-467.

22. Aikawa J, Yamashita T, Nishiyama M, Horinouchi S, Beppu T: Effects of glycosylation on the secretion and enzyme activity of Mucor rennin, an aspartic proteinase of Mucor pusillus, produced by recombinant yeast. J Biol Chem 1990, 265(23):13955-13959.

23. Gray GL, Hayenga K, Cullen D, Wilson LJ, Norton S: Primary structure of Mucor miehei aspartyl protease: evidence for a zymogen intermediate. Gene 1986, 48(1):41-53.

24. Murakami K, Aikawa J, Wada M, Horinouchi S, Beppu T: A Mucor pusillus mutant defective in asparagine-linked glycosylation. J Bacteriol 1994, 176(9):2635-2639.

25. Shakin-Eshleman SH, Spitalnik SL, Kasturi L: The amino acid at the $X$ position of an Asn-X-Ser sequon is an important determinant of $\mathrm{N}$-linked core-glycosylation efficiency. J Biol Chem 1996, 271(11):6363-6366.

doi:10.1186/1471-2180-13-250

Cite this article as: Gama Salgado et al: Cloning and expression of an active aspartic proteinase from Mucor circinelloides in Pichia pastoris. BMC Microbiology 2013 13:250.

\section{Submit your next manuscript to BioMed Central and take full advantage of:}

- Convenient online submission

- Thorough peer review

- No space constraints or color figure charges

- Immediate publication on acceptance

- Inclusion in PubMed, CAS, Scopus and Google Scholar

- Research which is freely available for redistribution 